\title{
EFFICACY OF ENTOMOPATHOGENIC FUNGI Verticillium (=Lecanicillium) lecanii Zimm. (Hypocreales:Clavicipitaceae) TOWARD CONTROLLING Bemisiatabaci Genn (Hemiptera:Aleyrodidae) ON SOYBEAN
}

\author{
Rangga Rakhmad', Sofia Ery Rahayu' ${ }^{1}$, Yusmani Prayogo ${ }^{2}$ \\ ${ }^{1}$ Biology Faculty of Mathemathic and Natural Science State University of Malang \\ JL Semarang 5 Malang 65145, Indonesia \\ ${ }^{2}$ Indonesian Legumes and Tuber Crops Research Institute \\ Jl. Raya Kendalpayak km 8, PO Box 66 Malang 65101, Indonesia \\ E-mail: ${ }^{1}$ ranggarakhmad@gmail.com, ${ }^{2}$ manik_galek@yahoo.com
}

\begin{abstract}
BemisiatabaciGenn is a primary soybean pest in Indonesia. This pest infests soybean leaves, causing direct damage in the form of wilting leaves and necrosis, and indirect damage by the formation of powdery mildew and viral infections which decreases soybean production. Pest control using pesticide has diminishing effectiveness and also causes collateral pollution, which necessitate an alternative method of controlling $B$. tabaci. One such method is the use of entomopathogenic fungi Lecanicilliumlecanii. This research aims to find the effect of conidia density of the entomophatogenic fungiVerticillium(=Lecanicillium) lecanii (Hypocreales:Clavicipitaceae) Zimm towards Bemisiatabaci Genn under field conditions. This research uses the split plot method, with two factors, six treatments, and three replications. The treatment was done by spraying $L$. lecanii $10^{7} \mathrm{conidia} / \mathrm{ml}$ or $10^{9} \mathrm{conidia} / \mathrm{ml}$ every week or two weeks on soybean leaves. The results showed that $L$. lecanii application significantly decreased $B$. tabaci population. Conidia density of $10^{9} \mathrm{conidia/}$ $\mathrm{ml}$ per week resulted the most significantly effective decreasing of $B$. tabacipopulation.
\end{abstract}

Keywords: Bemisiatabaci.Lecaniclilliumlecanii, Ethomopathogenic fungi, Soybean

\section{INTRODUCTION}

Soybean production in Indonesia has been in decline since 1992, with a declining average up to $64 \%$. This condition is contradictory with the increasing consumption rate of soybean in Indonesia, that in 2004, the import value of soybean increase, becoming twice of the national production value (Marwoto, 2007). One reason for this decline is pest infestation, one example being $B$. tabaci. This insect is a primary soybean pest as it is a vector of important soybean viruses that has spread widely in Indonesia (Tengkano et al., 2007).

B. tabaci has become difficult to control as its optimal temperature sits at around $25^{\circ} \mathrm{C}$, which is also the optimal temperature for soybean growth (Irawan, 2006; Nillson, 2001). B. tabacicontrol using pesticide succeeded for a time, until it was widely known that pesticide is detrimental to nature, whether economically or ecologically. B. tabaci has also been known to form resistances towards certain pesticides such as Bifenthrin, alpha-cypermethrin, pirimiphos-methyl, endosulfan, Imidacloprid, as reported by the Greeks (Roditakis et al., 2005).

One solution in dealing with $B$. tabacicontrol which is currently being developed is the use of entomophatogenic fungi Lecanicillium lecanii. L. lecanii has been known to be epizootic towards some insect species, especially form ordo Hemiptera. L. lecanii has been known to cause mortality on the aphid Myzus persicae up until 95\% (Diaz et at al., 2009). Other pests such as Ricania simulans, Coccus viridis, Fiorinia externa,Ceroplastes japoni-

ISSN 2413-0877 (C) 2015 The Authors.

Published by KnowledgeE Publishing Services This is an open access article under the CC BY-NC-ND license (http://creativecommons.org/licenses/by-nc-nd/4.0)

Selection and Peer-review under responsibility of the 3rd ICBS-2013

Doi http://dx.doi.org/10.18502/kls.v2i1.184 
cas, dan Coccus hesperidium has shown similar results to that of Aphids (Jackson dan Zemmenick, 2009; Marcelino et at al., 2009; Liu et at al., 2009 and Liu et at al., 2011). Some laboratory experiments has shown that $L$. lecanii as a pathogen of $B$. tabacicauses a high enough mortality (Wang et at al., 2007; Lazerg, 2007). However field experiments on this subject are not as common, and are therefore required to test the efficacy of $L$. lecanii in controlling $B$. tabaci. This research aims to find which formulation is most effective in controlling B. tabaci.

\section{MATERIALS AND METHODS}

\section{L. lecanii Conidia Preparation}

Isolate of L. lecanii LT-JTM11 obtained from culture grown on rice medium for 21 days. This culture is then crushed with blender and then filtered using filter. The result is then diluted to $1 \mathrm{~L}$, and then added with Tween-80 $5 \mathrm{~mL}$ for each liter of $L$. lecanii conidia.

\section{B. tabaci Population Measurement}

Data collection is done using yellow sticky trap method. On day 13 after planting, before $L$. lecanii conidia are applied, a preliminary test is done using the yellow sticky trap to estimate the starting population of $B$. tabaci.

\section{Field Experiment}

The experiment was done from June, 14 until August, 28, 2011 in Muneng Experimental Garden, Indonesian Legumes and Tuber Crops Research Institute, Probolinggo East Java. This experiment used the split plot method, with two factors, six treatments, and three replications. The treatments used are conidia density and application frequency (once and twice a week).

Treatments on soybeans are carried out on evenings at 16.00 PM (avoiding direct sunlight). Treatment combinations on soybean are as follows; (1) 14, 21, 28, 35, 42, 47, 56, 61 and 70 days after planting (once a week) with conidia density of $10^{7}$ conidia/mL. (2) 14,28 , 42,56 , and 70 days after planting (twice a week) with conidia density of $10^{7} \mathrm{conidia} / \mathrm{mL}$. (3) $14,21,28,35,42,47,56,61$ and 70 days after planting (once a week) with conidia density of $10^{\circ}$ conidia/mL. (4) $14,28,42,56$, and 70 days after planting (twice a week) with conidia density of $10^{\circ}$ conidia/mL. (5) tiametoksan (an insecticide) $141 \mathrm{gr} / \mathrm{L}$ on day $14,2128,38,45$, 52 and 59 after planting, and (6) control (without treatment). Spraying is done after diluting $1 \mathrm{~L}$ of conidia concentrate into $2 \mathrm{~L}$, therefore there are $10 \mathrm{~L}$ for each treatments. Data collection is done on day 15 after planting (a day after treatment using L. lecanii) and continued on day $22,29,36,43,48,55,62$, and 70 after planting.

\section{RESULTS AND DISCUSSION}

\section{Results}

Based on ANOVA result, it was shown that conidia density treatment and application frequency on day 22 after planting has $F$ score $(4,06)>F$ table $(2,71)$, while the main variety treatment and combination treatment did not show a significant difference, meaning that conidia application of $L$. lecanii effect $B$. tabaci population on day 22 after planting. 
Table 1. ANOVA result of $B$. tabacipopulation on Soybean plants applied with L. lecanii on day15 until day 70 after planting

\begin{tabular}{|c|c|c|c|c|c|c|c|c|c|}
\hline \multirow[b]{2}{*}{ Treatment } & \multicolumn{9}{|c|}{ Days after planting } \\
\hline & 15 & 22 & 29 & 36 & 43 & 48 & 55 & 62 & 70 \\
\hline $\begin{array}{l}\text { Wilis and } \\
\text { Argomulyo } \\
\text { Variety } \\
\text { treatment }\end{array}$ & $\begin{array}{c}2.63 \\
(18.20)\end{array}$ & $\begin{array}{c}3.50 \\
(18.20)\end{array}$ & $\begin{array}{c}2.07 \\
(18.20)\end{array}$ & $\begin{array}{c}0.09 \\
(18.20)\end{array}$ & $\begin{array}{c}4.87 \\
(18.20)\end{array}$ & $\begin{array}{c}0.15 \\
(18.20)\end{array}$ & $\begin{array}{c}0.96 \\
(18.20)\end{array}$ & $\begin{array}{c}0.05 \\
(18.20)\end{array}$ & $\begin{array}{c}2.27 \\
(18.20)\end{array}$ \\
\hline $\begin{array}{c}\text { Conidia } \\
\text { treatment \& } \\
\text { aplication } \\
\text { frequency }\end{array}$ & $\begin{array}{c}1.23 \\
(2.71)\end{array}$ & $\begin{array}{l}4.06 \\
(2.71)\end{array}$ & $\begin{array}{c}1.43 \\
(2.71)\end{array}$ & $\begin{array}{c}0.81 \\
(2.71)\end{array}$ & $\begin{array}{c}0.75 \\
(2.71)\end{array}$ & $\begin{array}{c}1.29 \\
(2.71)\end{array}$ & $\begin{array}{c}1.89 \\
(2.71)\end{array}$ & $\begin{array}{c}0.30 \\
(2.71)\end{array}$ & $\begin{array}{c}1.17 \\
(2.71)\end{array}$ \\
\hline $\begin{array}{c}\text { Combination } \\
\text { treatment }\end{array}$ & $\begin{array}{c}0.36 \\
(2.71)\end{array}$ & $\begin{array}{c}0.35 \\
(2.71)\end{array}$ & $\begin{array}{c}0.87 \\
(2.71)\end{array}$ & $\begin{array}{l}1.40 \\
(2.71)\end{array}$ & $\begin{array}{l}2.30 \\
(2.71)\end{array}$ & $\begin{array}{l}0.77 \\
(2.71)\end{array}$ & $\begin{array}{c}1.17 \\
(2.71)\end{array}$ & $\begin{array}{l}1.06 \\
(2.71)\end{array}$ & $\begin{array}{c}0.73 \\
(2.71)\end{array}$ \\
\hline
\end{tabular}

Explanation: Numbers without brackets shows the F score

Numbers with brackets shows the $\mathrm{F}$ table

Bold numbers shows that the F score is significant compared to the $\mathrm{F}$ table.

Based on ANOVA result of day 22 after planting followed with LSD test with $5 \%$ rate to find which conidia density and application frequency shows significant difference, which formulation of $L$. lecanii is most effective can be concluded (Table 2)

Table 2. Results of LSD of day 22 after planting

\begin{tabular}{lc}
\hline \multicolumn{1}{c}{ Treatment } & $\begin{array}{c}\text { B. tabaci population } \\
\text { day } 22 \text { after planting }\end{array}$ \\
\hline $\begin{array}{l}10^{7} \text { conidia/mL \& } \\
\text { once week aplication }\end{array}$ & $115.5^{\text {ab }}$ \\
\hline $\begin{array}{l}10^{7} \text { conidia/mL \& } \\
\text { twice week aplication }\end{array}$ & $115.5^{\text {ab }}$ \\
\hline $\begin{array}{l}10^{9} \text { conidia/mL \& } \\
\text { once week aplication }\end{array}$ & $90.3^{\mathrm{a}}$ \\
\hline $\begin{array}{l}10^{9} \text { conidia/mL \& } \\
\text { twice week aplication }\end{array}$ & $126.3^{\mathrm{ab}}$ \\
\hline Tiametoxan & $115.5^{\mathrm{ab}}$ \\
\hline Control & $155.1^{\mathrm{b}}$ \\
\hline
\end{tabular}

Explanation: Numbers followed by the same letter on different columns are not significantly different according to LSD 5\%

\section{Discussion}

The result showed that the formulation of $L$. lecanii was able to decrease $B$. tabaci population after 14 days after planting significantly, with $7^{\text {th }}$ days interval, until the $22^{\text {nd }}$ day after planting. The time needed by $L$. lecanii to decrease the population of $B$. tabacisignificantly, as shown by this research is incubation time. Incubation time is the time needed by an entomopathogenic fungi to cause death or epizootic on its host insect (Prayogo, 2012). Incubation time depends on germination rate of fungi on its host, where the host will finally be colonized by hyphae. This process happens in some steps before the fungi can kill the host. The result of LSD test $(5 \%)$ showed that there was a significant difference only on treatment with $10^{\circ} \mathrm{conidia} / \mathrm{mL}$ and once a week application compare to the control treatment. Other 
treatment were not proven to have a significant difference compare to control treatment, as each population of $B$. tabacion table 1 had the same notation. Conidia density of 109 was the highest density of conidia used in this research. Previous research has shown that a high conidia density of $L$. lecanii can increase infection rate against $B$. tabaci. (Forero, 2006). A high conidia density increases the chance of conidia sticking into its host body. The same is also true for application frequency, which increases the chance of conidia sticking into the insect.

Results other than the $22^{\text {nd }}$ day which are not significantly different showed that there are factoras that inhibit the infection of $L$. lecanii towards $B$. tabaci. Infection starts with the attachment of conidia to epicuticle of an insect. This process is helped by secretion from conidia that enable it to stick to insect cuticle (Schreiter et al., 1994 and Askary et al., 1999 in Liu et al., 2011). The infection process of entomopathogenic fungi, if viewed from the outside will show the insect covered with L. lecanii hyphae (Liu et al., 2009 dan Liu at al., 2011).

Jackson and Zemenick, (2009) explains that wind can cause L. lecanii conidia that have stuck to Coccus viriidis integument to unstuck, decreasing effication of $L$. lecanii in the field. Research on $L$. lecanii effication was carried out in dry season, with strong wind condition. This condition could have affected L. lecanii conidia that have stuck on B. tabaci, hence there were no significant decrease in $B$. tabaci population after day 22. Humidity during research was $50-55 \%$, while temperature ranged between $25^{\circ} \mathrm{C}-35^{\circ} \mathrm{C}$.

Prayogo (2009) reported that $L$. lecanii can achieve optimal growth, causing mortality on $R$. linearis in temperatures ranging from $25^{\circ} \mathrm{C}-29^{\circ} \mathrm{C}$. The temperature range of the experimental garden was around $25^{\circ} \mathrm{C}-35^{\circ} \mathrm{C}$, which is within the range for optimal growth of $L$. lecanii.

\section{CONCLUSION}

There is was significant difference on day 22 after planting with once a week application, while there were no significant difference on day $15,29,36,43,48,55,62$, and 70 days after planting. The significant difference on day 22 was found on the $10^{9} \mathrm{conida} / \mathrm{mL}$ with once a week application, while other treatments showed results that were not significantly different with control treatment.

\section{REFFERENCES}

Askary, H., N. Benhamou, and J. Brodeur. 1999. Ultrastructural and cytochemical characterization of aphid invasion by the hyphomycete Verticillium lecanii. Journal of Invertebrate Pathology 74 (1), 1-13.

Diaz, B.M., M. Oggerin, C.C.L. Lastra, V. Rubio, and A. Fereres. 2009. Characterization and virulence of Lecanicillium lecanii against different aphid species. BioControl : 1-4

Forero, P. 2006. Desarrollo de un bioplaguicida para el control de la mosca blanca Bemisia tabaci. Boletin Tecnico: 1-58

Irawan, A.W. 2006. Budidaya tanaman kedelai (Glycine max (L.) Merill). Skripsi tidak diterbitkan. 
Lazreg, F., A. Shaukat, R. Shunxiang, dan A. Muhammad. 2007. Biological Characteristic and Pathogenicity of Verticillium Lecanii Against B. tabaci (Homoptera:Aleyrodidae) on Eggplant. Pak. Entomol. 29:2.

Liu, W., Y. Xie, J. Xue, Y. Gao, Y.Z. Zhang, Z. Xiaomin, dan J. Tan. 2009. Histopathological changes of Ceroplastes japonicus infected by Lecanicillium lecanii. Journal of Invertebrate Pathology, (Online) 101 96-105, (www.elsevier.com/locate/yijpa), Diakses 20 Juli 2012.

Liu, W., Y. Xie, J. Xue, Y. Zhang, dan X. Zhang. 2011. Ultrastructural and cytochemical characterization of brown soft scale Coccushesperidum (Hemiptera: Coccidae) infected by the Lecanicillium lecanii (Ascomycota: Hypocreales). Micron 42: 717(www.elsevier.com/locate/micron), Diakses pada 20 Juli 2012.

Marwoto. 2007. Dukungan Pengendalian Hama Terpadu dalam Program Bangkit Kedelai. Iptek Tanaman Pangan. 2(1): 79-80

Marcellino, J.A.P., S. Gouli, L.P. Parker, M. Skinner, dan R. Giordanno. 2009. Entomopathogenic activity of a variety of the fungus, Colletotrichum acutatum, recovered from the elongate hemlock scale, Fiorinia externa. Journal of Insect Science. 9;3.

Nillson, T. 2001. A risk assessment of bemisia tabaci and its quarantine status in Sweden. Thesis tidak diterbitkan. Danish:Swedish Horticulture Programme.

Roditakis, E., E. Nikos, dan A. Tsagkarakou. 2005. Insecticide resistance in Bemisia tabaci (Homoptera: Aleyrodidae) populationsfrom Crete. Society of. Pest Manag Sci (61):577578

Schreiter, G., T.M. Butt, A. Beckett, S. Vestergaard, and G. Moritz. 1994. Invasion anddevelopment of Verticillium lecanii in the western flower thrips, Frankliniella occidentalis. Mycological Research 98 (9), 1025-1034.

Stansly, P.A., and E. S. Naranjo. 2010. Bemisia: Bionomics and Management of a Global Pest. New York: Springer Dordrecht Heidelberg London.

Tengkano, W., Supriyatin, Suharsono, P. Bedjo, Yusmani, dan Purwantoro. 2007. Status Hama Kedelai dan Musuh Alami pada Agroekosistem Lahan Kering Masam Lampung. Iptek Tanaman Pangan 3: 94-95

Prayogo, Y. 2009. Kajian Cendawan Entomopatogen Lecanicillium lecanii (Zimm.) (Viegas) Zare Gams untuk Menekan Perkembangan Telur Hama Penghisap Polong Kedelai Riptortus linearis (F.) (Hemiptera:Alydidae). Desertasi Tidak diterbitkan

Prayogo, Y. 2012. Keefektifan Cendawan Entomopatogen Lecanicillium lecanii (Zare \& Gams) Terhadap Bemisia Tabaci GEN. Sebagai Vektor Soybean Mozaic Virus (SMV) Pada Tanaman Kedelai. (Online),( http://jurnal.peipfi-komdasulsel.org/wp-content/ uploads/2012/01/6-Yusmni-Lecanicillium-lecanii-Bemisia-tabaci.pdf), Diakses 29 Juli 2012.

Wang, L., J. Huang, M. You, X. Guan, and B. Liu. 2007. Toxicity and feeding deterence of crude toxin extracts of Lecanicillium lecanii (Hyphomycetes) against sweet potato whitefly Bemisia tabaci (Homoptera: Aleyrodidae). Pest Manag Sci 63(4): 381-387. 